\title{
Olimpik Eğitimin yaygınlaştırılmasında Üniversite Oyunlarının etkileri
}

\author{
PInar Güzel ${ }^{1}$ \\ Selhan Özbey ${ }^{2}$ \\ Meliha Atalay Noordegraff ${ }^{3}$
}

\section{Özet}

$\mathrm{Bu}$ araştırmada amaç; nitel araştırma yöntemi ile ve örnek olay ve fenomenoloji araştırma desenleri kullanılarak Üniversite Yaz Oyunları'nın olimpik eğitimin yaygınlaştırılmasında ne düzeyde etkili olduğunu ortaya çıkarmaktır. Amaca ulaşabilmek için araştırmada uluslararası spor organizasyonları içerisinde Olimpiyat Oyunlarının ardından en büyük spor organizasyonlarından biri olan Üniversite Oyunları örnek olay olarak alınmıştır. Çalışmada, amaçlı örnekleme yöntemi kullanılarak 23. Üniversite Yaz Oyunları'nın İzmir' de yapılmasının ardından oyunlara destek veren 4 üniversitenin Beden Eğitimi ve Spor Yüksekokulu yönetim kadrosundaki 12 kişi ile görüşme yöntemi tekniği uygulanarak düşünceleri alınmıştır. Yöneticilerin; organizasyon sonrasında yaşanan deneyimlerin, düşüncelerin düzeyi ve olimpik eğitim hakkında geleceğin spor yöneticilerine, beden eğitimi öğretmenlerine ve antrenörlerine nasıl aktardığ Görüşmelerin betimsel ve içerik analiz yöntemi kullanılarak yapılan analizi sonucunda; katılımcılara yöneltilen sorular ile elde edilen verileri kodlamalar haline dönüştürülmüş ve bu kodlamalar neticesinde ana temalar ve bunlara ait alt temalar oluşmuştur. Katılimcilar Olimpizm anlayışının eğitim düzeyi, kültür anlayışı gibi faktörlere bağlı olarak Universiade 2005, İzmir'de rol aldığını ifade etmişlerdir. Ayrıca Uluslararası organizasyonların spor kültürünü arttırmada önemli bir katkı sağladığını ve bu kültürün yaratılmasında da Olimpik Eğitimin yararlı olabilecek bir program olduğu sonucu ortaya çıkmıştır. Olimpik Eğitim Programının Dünyada özellikle gelişmiş ülkeler tarafından uygulanmasına rağmen, ülkemizde bu program ile ilgili çalışmaların çok yeni ve az sayıda olması nedeniyle, ilgili birimlerin kurulması önerilmektedir. Bu programların başta Milli Eğitim Bakanlığı olmak üzere ilgili kuruluşlarca da desteklenmesi gerektiği de ortaya çıkan diğger sonuçlar arasında yer almıştır.

Anahtar Kelimeler: Olimpik Eğitim; Uluslararası Spor Organizasyonlar1; Universiade; Spor Yöneticisi

\footnotetext{
${ }^{1}$ [Celal Bayar Üniversitesi, Beden Eğitimi ve Spor Yüksekokulu, Manisa, Türkiye, pinar.guzel@bayar.edu.tr]

2 [Celal Bayar Üniversitesi, Beden Eğitimi ve Spor Yüksekokulu, Manisa, Türkiye, selhanozbey@ gmail.com]

3 [Serbest Araştırmacı, Hollanda, melihaatalay@ yahoo.com]
} 
Güzel P., Özbey S., Atalay Noordegraff M. (2012). Olimpik eğitimin yaygınlaştırılmasında üniversite oyunlarının etkileri. Uluslararası İnsan Bilimleri Dergisi [Bağlantıda]. 9:1. Erişim: http://www.insanbilimleri.com doi: 10.14687/ijhs.v9i1.2099

\title{
Effects of Universiade to spread out Olympic Education
}

\begin{abstract}
The aim of this study was to expose the effects of 23rd Universiade Summer Games for spreading out the Olympic Education using the qualitative research method and case study and fenomenelogy models. In this study University Games which comes from one of the biggest sport organizations after the Olympic Games is taken as a case study. To reach this aim, opinions of the 4 Physical Education and Sports University's administrator -12 interviewers- that give the support to the 23rd University Summer Games in İzmir are taken with the techniques of the interview method. It is applied to their thoughts, experiences and profits after the end of this organization and also is wanted to learn how these administrators transfer the Olympic education "that must be adopt as a life philosophy" to the future's sports managers, physical education teachers and the trainers. The results of the questions turned into codes with the qualitative research method using descriptive and content analysis models. With these main themes, some other related themes have found. These codes showed us; Participators express that understanding of Olympism had part in Universiade 2005, with the factors like education level, culture comprehension. Furthermore it is seemed that International organizations have an important positive contribution for increasing sports culture. And creating this culture it is came out that Olympic education programme could help for this aim. Although Olympic Education Programme has been known by the developed countries, the studies for becoming widespread are needed to take part in all parts of Turkish education system. One of other important result of the codes is the programme must support with our National Education Ministry and the other Institutions.
\end{abstract}

Key Words: Olympic Education, International Sports Organizations, Universiade, Sport Administrator

\section{Giriş}

Olimpizm bedene, iradeye ve zihne özgün nitelikleri yücelterek, dengeli bir biçimde bütünleştirmekte ve sporu kültür ve eğitim ile kaynaştırarak, çaba göstermenin, iyi örneklerin eğitsel değerinin ve evrensel temel ahlak ilkelerine saygının verdiği mutluluğa dayalı bir yaşam biçimi yaratmayı amaçlamaktadır (Hsu, 2000). Hunterformer (2001), Olimpizmin dünyadaki insanları birleştiren bir araç olduğuna inanır ve bu idealleri günlük hayatlarına aktarabilen daha fazla bireye sahip olunabilirse, bu felsefenin büyük oranda dünyamızı etkileyebileceğini savunur. 
Güzel P., Özbey S., Atalay Noordegraff M. (2012). Olimpik eğitimin yaygınlaştırılmasında üniversite oyunlarının etkileri. Uluslararası Insan Bilimleri Dergisi [Bağlantıda]. 9:1. Erişim: http://www.insanbilimleri.com doi: 10.14687/ijhs.v9i1.2099

Olimpizm anlayışına dayanan Olimpik Hareket kavramı, 19.yy. sonlarında Avrupa'da ortaya çıkan “Uluslararası Barış Hareketi”nin ve “Uluslararası Spor Hareketi”nin bir parçasıdır. Bu hareket Coubertin'in "her spor her insan içindir” anlayışından yola çıkarak spor yolu ile gençlerin eğitiminin sağlanması ve ulusların, farklı kültürlerin ve inançların barışa destek olmaları yönünde gerçekleştirilmiştir (Arnold, 1996). Olimpik Hareket, Olimpik Antlaşma’yı rehber olarak benimseyen örgütleri, sporcuları ve diğer kişileri Uluslararası Olimpiyat Komitesi (IOC)'nin otoritesi altında toplar (Olympic Charter, 2007). Olimpik hareketin amacı, spor sayesinde gençleri eğiterek daha iyi ve barış dolu bir dünya yaratmaya katkıda bulunmaktır (Loland, 1995). Olimpik Hareketin kurucusu Coubertin'in hedefi de modern sporu okul müfredatının bütünleyici bir parçası haline getirmek ve böylece, müfredata hem bedeni hem de düşünceyi kapsayan bir spor eğitimi katılmasını teklif etmektir (Muller, 2004). Olimpik eğitim, Olimpizmi öğretmede bir öğrenme sürecidir; katılımcılar bilgi kazanmak, Olimpik ilkeleri anlamak, denemek ve yayılmasını sağlamak konularında cesaretlendirilir (Georgiadis, 2001). Naruka (2000)' ya göre, Olimpik eğitimin bakış açıları ve avantajlarında etkin olan bazı faktörler vardır. Bu faktörler; yaşam kalitesini geliştirme gücü, en uygun fiziksel, zihinsel ve sosyal becerileri için zengin bir materyale sahip olması, sağlık ve geleceğe dair programlar ile yaşam şeklini geliştirmeyi hedeflemesi, gelenekleri ve çeşitli ülkelerin kültürlerini öğrenebilme, programların tüm yaş gruplarını, kategorileri ve farklı insan yapılarını kapsaması ve gençlerin spor ile birbirlerini daha iyi anlamalarına, arkadaşlık kurmalarına ve daha barışçıl bir dünya kurulmasına yardım etmesidir. Gutenberg okullarda olimpik eğitimin tüm yaşamı ilgilendiren, evrensel bir eğitim yaklaşımı olduğunu savunur (Gutenberg, 1999). Üniversite eğitimi ve spor faaliyetleri de bu eğitimin önemli bir parçasıdır. Bu düşünceden yola çıkarak öncelikle Üniversite Oyunları'nın etkilerinin incelenmesi yerinde olacaktır.

"Universiade" kelimesi üniversite öğrencilerinin olimpiyatları anlamına gelen Üniversite (University) ve Olimpiyat (Olympiad) kelimelerinin birleşmesinden oluşmaktadır. Universiade, birçok spor dalını bir araya getiren bir kültür ve spor festivali olması nedeniyle dünyanın en önemli spor etkinliklerinden birisidir (Universiade, 2005). 1959 yılında İtalya'nın Torino kentinde düzenlenmeye başlayan Üniversite Oyunları iki yılda bir yaz ve kış oyunları olarak düzenlenmektedir. Türkiye, İzmir'de 23. Yaz Oyunlarına ve Erzurum'da 25. Kış Oyunlarına ev sahipliği yapmıştır. Universiade 2006 resmi raporuna göre Şekil 1'de verilen tüm sayılar organizasyonun ne kadar büyük ve kapsamlı olduğunu göstermektedir. 
Güzel P., Özbey S., Atalay Noordegraff M. (2012). Olimpik eğitimin yaygınlaştırılmasında üniversite oyunlarının etkileri. Uluslararası İnsan Bilimleri Dergisi [Bağlantıda]. 9:1. Erişim: http://www.insanbilimleri.com doi: 10.14687/ijhs.v9i1.2099

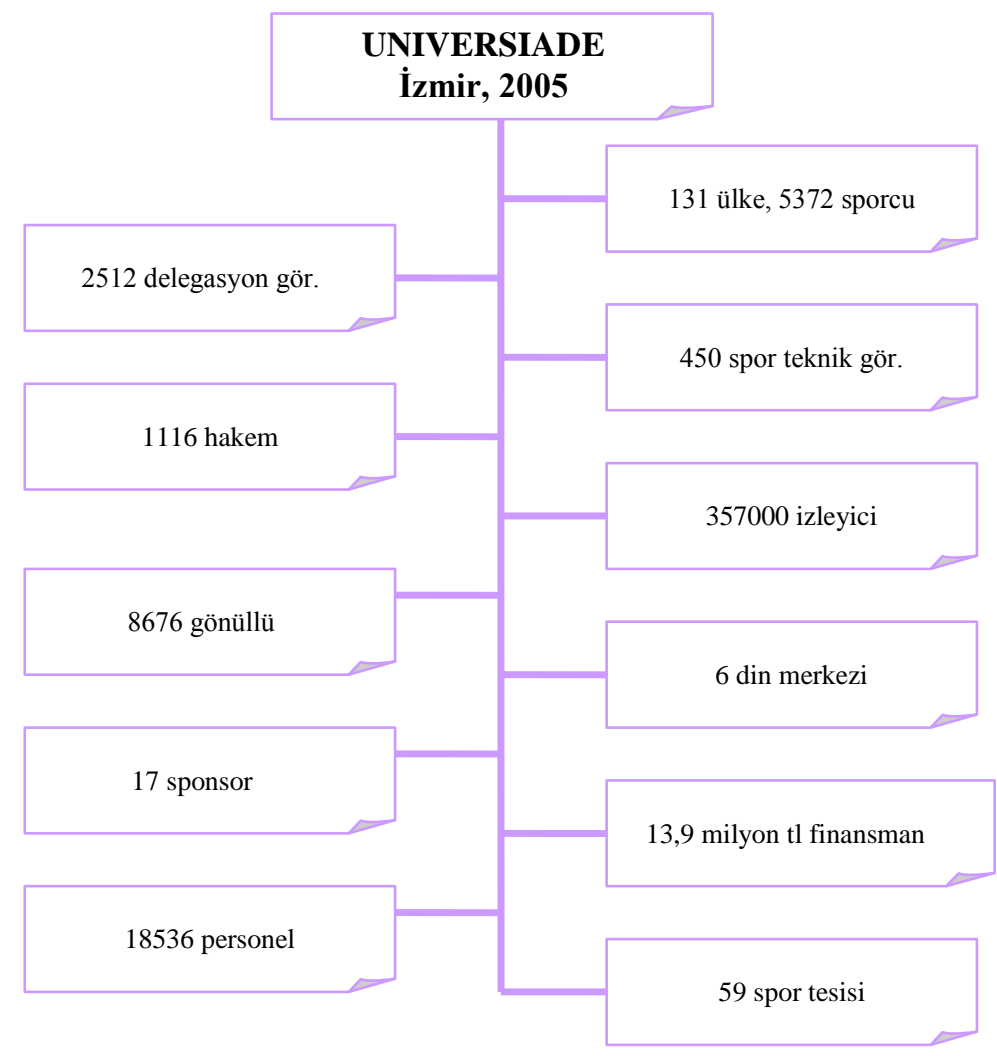

Şekil 1. Sayılarla Üniversite Oyunları-2005, İzmir (Universiade Official Report, 2006)

1970’li yıllardan itibaren Olimpik Eğitim, Olimpik Hareketin yaratıcısı Coubertin tarafından sürekli bir gelişim içine girmiş ve dünya genelinde destek görmüş, özellikle Yunanistan, Almanya, Belçika, Rusya, Kanada, Büyük Britanya, Amerika, Kore, vb.ülkelerce benimsenerek uygulanmaya başlamıştır (IOA, 2008). Bu nedenle, Olimpiyat Oyunları ve Üniversite Oyunları gibi büyük çaplı uluslararası organizasyonlar Olimpik Eğitimin uygulanabileceği uygun alanlardır. Bu uygulamalar, 1992-Barselona, 1996-Atlanta Olimpiyat Oyunları ile başlamış ve 2000 yılında Sidney Olimpiyat Oyunları düzenlenen “Sidney Olimpik Kültür ve Eğitim Programı”nda büyük bir ivme kazanmıştır (Garcia, 2000). Olimpik Eğitim çalışmaları son örneklerine 2008 yılında gerçekleşen Beijing-2008 Olimpiyat Oyunları'nda rastlanmıştır. Burada "Hearth to Hearth Program" adında Beijing Olimpiyat Oyunları Organizasyon Komitesi (BOCOG) ve Çin Eğitim Bakanlığı işbirliği ile bir eğitim programı gerçekleştirilmiştir. 2006 yılının ortalarında başlanan bu çalışmada 200'den fazla ilk ve orta dereceli okul ve 205 üye ülkenin Milli Olimpiyat Komiteleri yer almıştır (Beijing, 2008). 
Güzel P., Özbey S., Atalay Noordegraff M. (2012). Olimpik eğitimin yaygınlaştırılmasında üniversite oyunlarının etkileri. Uluslararası İnsan Bilimleri Dergisi [Bağlantıda]. 9:1. Erişim: http://www.insanbilimleri.com doi: 10.14687/ijhs.v9i1.2099

Olimpik Eğitim programlarının geliştirilmesi ile Olimpik idealler doğrultusunda insanlığın dayanışma duygusu, hoşgörü ve fair-play’ a dayalı karşılıklı saygıyı geliştirme, farklı kültürlere saygı duyma, çevreyi koruma ile insanın kişiliğinin zenginleştirilmesi gibi değerler kazanılabilecektir. Bu doğrultuda araştırmanın amacı; nitel araştırma yöntemi ile 23. Üniversite Yaz oyunlarının Olimpik Eğitimin yaygınlaştırılmasında ne düzeyde etkili olduğunun araştırılmasıdır.

\section{Yöntem}

\section{Araştırmanın Modeli}

Araştırmada, Universiade 2005 'in ardından, Türkiye'de ki Olimpik Eğitim anlayışı ve uygulamalarının araştırılması ve Olimpik Eğitimin yaygınlaştırılmasında oyunlarda yöneticilik deneyimi yaşamış olan ve üniversitede görev yapan Spor Yöneticilerinin görüşlerinin ortaya çıkarılması amacıyla nitel araştırma teknikleri kullanılmıştır. Bu model katılımcıların düşüncelerini, deneyimlerini, beklentilerini ve önerilerini ortaya çıkarmada etkili olacağının düşünülmesi nedeniyle tercih edilmiştir (Yıldırım \& Şimşek, 2005). Araştırma desenini "durum (örnek olay) araştırması" ve "fenomenoloji (olgubilim)" yaklaşımları oluşturmuştur.

\section{Katılımcilar}

Araştırmaya İzmir ilinde Ege Ün. Beden Eğitimi ve Spor Yüksekokulu (BESYO) ve 9 Eylül Ün. Eğitim Fakültesi, Beden Eğitimi Öğretmenliği Bölümü, Manisa ilinde Celal Bayar Ün.-BESYO ve Aydın ilinde Adnan Menderes Ün.-BESYO olarak oyunlara ev sahipliği yapan dört farklı üniversitede yönetici olan "Yüksekokul Müdürleri”, "Müdür Yardımcısı" ve "Bölüm Başkanları” katılmıştır.

Araştırmada, katılımcı seçiminde uluslararası spor organizasyonlarında görev yapan spor yöneticilerinin Olimpizm ve Olimpik Eğitim anlayışını en iyi yansıtabilmesi amacıyla, örneklem seçiminde "amaçlı örnekleme" yöntemi kullanılmıştır. Amaçlı örnekleme yöntemlerinden de tipik durum örnekleme yöntemi tercih edilmiştir. Bu yöntemde amaç, araştırmacının yeni bir uygulamayı veya bir yeniliği tanıtmak istemesi durumunda, bu uygulamanın yapıldığı veya yeniliğin olduğu bir dizi durum arasından, en tipik bir veya birkaç tanesini saptayarak bulmaya çalışmasıdır (Yıldırım\& Şimşek, 2005). 
Güzel P., Özbey S., Atalay Noordegraff M. (2012). Olimpik eğitimin yaygınlaștırılmasında üniversite oyunlarının etkileri. Uluslararası İnsan Bilimleri Dergisi [Bağlantıda]. 9:1. Erişim: http://www.insanbilimleri.com doi: 10.14687/ijhs.v9i1.2099

\section{Araştırma Verilerinin Toplanması}

Araştırmada veri toplama yöntemi olarak, "görüşme" yöntemi kullanılmıştır. Araştırma da görüşme yönteminde "görüşme formu yöntemi” ve "sohbet tarzı görüşme yöntemi" seçilmiştir. Bu tekniklerle araştırmacı, katılımcıları sınırlamadan, görüşmenin akışına bağlı olarak, düşüncelerini kısıtlamadan anlatmalarını sağlamıştır. Her iki yöntemin birlikte tercih edilmesinin nedeni, araştırmacının katılımcılar ile yaptığı görüşmeler sırasında konu ile ilgili daha kapsamlı bilgiye ulaşmak adına soru çeşitliliğini yaratabilmesidir. Çalışmada, araştırmacı tarafından, katılımcılar ile Universiade 2005 sonrasında ön görüşme yapılmıştır. Ön görüşmede, araştırma hakkında gerekli bilgi verilerek randevular alınmıştır. Araştırma örneklemini teşkil eden katılımcılar ile görev yaptıkları yerde, yüz yüze görüşme yapılmıştır. Ayrıca, görüşme yapılan katılımcılar hakkında genel kişisel bilgiler edinmek için, araştırmacı tarafından hazırlanmış "bilgi formu” kullanılmıştır. $\mathrm{Bu}$ süreç yaklaşık 1 ay içerisinde gerçekleştirilmiştir. Görüşmeler bir ses kayıt cihazıyla kaydedilmiş, ayrıca araştırmacı tarafından kısa notlar tutulmuştur. Kaydedilmiş bilgiler araştırmacı tarafından deşifre edilerek bilgisayar ortamında düz yazı haline getirilmiştir.

Görüşme formunun geliştirilmesi amacıyla, ilgili literatür taraması ve Türkiye Milli Olimpiyat Komitesi (TMOK) üyesi olan, aynı zamanda "İlköğretim Okullarında Spor Kültürü ve Olimpik Eğitim” adlı proje grubunda yer alan bir uzmanın görüşü esas alınmıştır.

\section{Araştırma Verilerinin Analizi}

Araştırmada, verilerin anlaşılır bir biçimde çözümlenmesi, neden sonuç ilişkilerinin irdelenerek birtakım sonuçlara ulaşılması ve bulguların yorumlanması için, nitel analiz yöntemlerinden "betimsel analiz" ve verilerin tanımlanması, birbirine benzeyen verilerin belirli kavramlar ve temalar çerçevesinde bir araya getirilmesi ve verilerin içinde saklı olabilecek gerçeklerin ortaya çıkarılması için “içerik analizi” yöntemi birlikte kullanılmıştır.

Araştırmada verilerin kodlanması, araştırmacı, nitel çalışma konusunda uzman bir akademisyen ve Olimpik Eğitim konusunda uzman bir akademisyenden oluşan üç kişilik bir grup tarafindan yapılmıştır. Oluşturulan temalar önce birbirinden bağımsız olarak değerlendirilmiş, daha sonra yapılan bir çalışma sonucu ortak bir kodlama oluşturulmuştur. Kodlamada her bir katılımcıya bir harf ve bir numara verilerek oluşturulmuştur. Araştırmada kullanılan kodlamada kısaltmalar listesi Tablo 1'de verilmiştir. 
Güzel P., Özbey S., Atalay Noordegraff M. (2012). Olimpik eğitimin yaygınlaştırılmasında üniversite oyunlarının etkileri. Uluslararası İnsan Bilimleri Dergisi [Bağlantıda]. 9:1. Erişim: http://www.insanbilimleri.com doi: 10.14687/ijhs.v9i1.2099

Tablo 1. Kodlama Sirasında Kullanılan Kodlama Kisaltmalar Listesi

\begin{tabular}{llllll}
\hline Katılımcılar & Kısaltmalar & Katılımcılar & Kısaltmalar & Katılımcılar & Kısaltmalar \\
\hline 1. Katılımc1 & A1 & 5. Katılımc1 & B2 & 9. Katılımc1 & C3 \\
2. Kat11ımc1 & A2 & 6. Katılımc1 & B3 & 10. Kat1lımc1 & C4 \\
3. Kat11ımc1 & A3 & 7. Kat1lımc1 & C1 & 11. Kat1lımc1 & C5 \\
4. Kat1lımc1 & B1 & 8. Katılımc1 & C2 & 12. Katılımc1 & D1 \\
\hline
\end{tabular}

Araştırmada yapılan görüşmeler sonucunda ortaya çıkan ana temalar Tablo 2'de aktarılmıştır.

Tablo 2: Görüşmeler Sonucu Ortaya Çıkan Ana Temalar

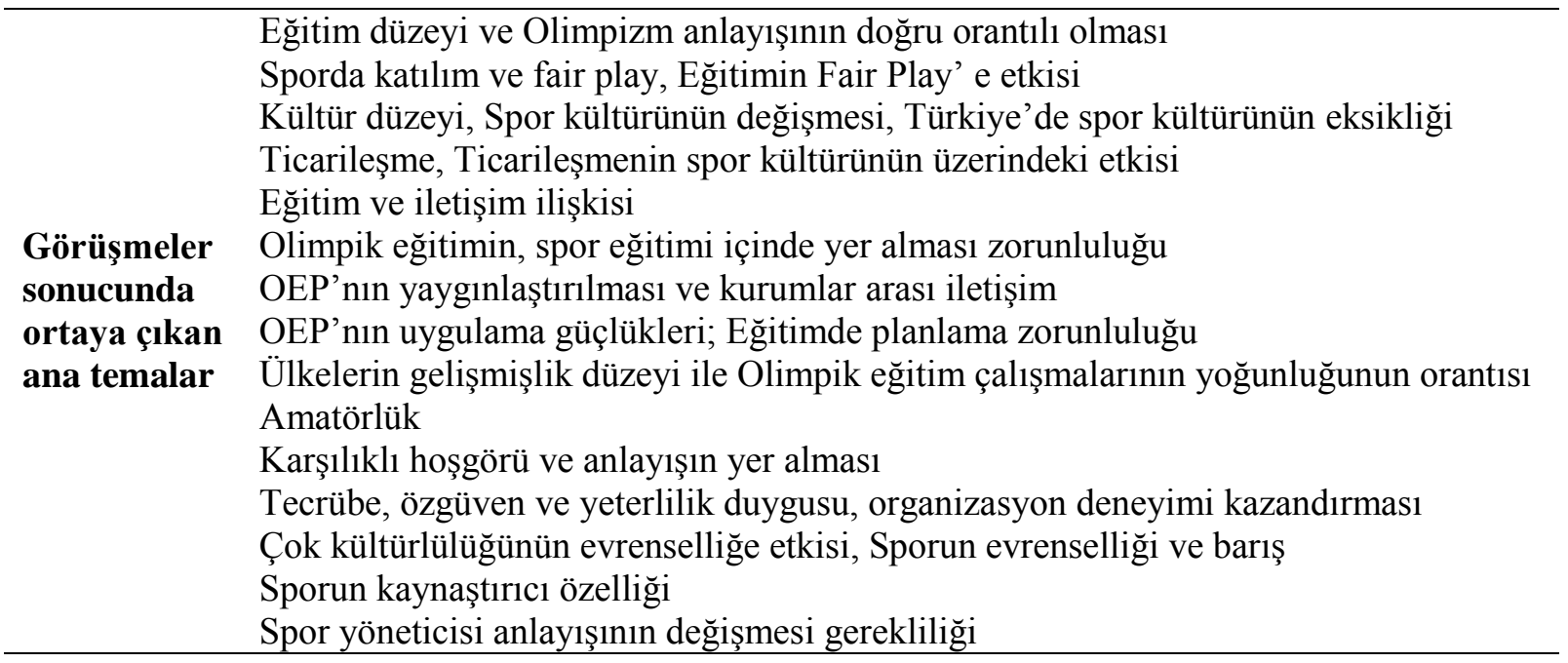

\section{Geçerlik- Güvenirlik}

Uluslararası Olimpik Akademi (IOA) Kütüphanesi (Olympia, Yunanistan) ve TMOK Kütüphanesi'nden ilk elden ve orijinal kaynaklara ulaşılarak araştırma için gerekli literatür temelinin oluşturulabilmesi için derinlemesine incelenmiş olması araştırmanın geçerlik ve güvenirliğini arttırmada önemli bir rol oynamıştır.

Bulguların kendi içerisinde tutarlı ve anlamlı olmasına dikkat edilmiştir. Elde edilen veriler daha önce literatür taraması sürecinde elde edilen kavramsal çerçeve ile uyumludur. $\mathrm{Bu}$ çerçeve veri toplamada rehber olmuş ve uygulamada pratiklik sağlamıştır. Araştırmada yapılan görüşmeler, araştırmacı tarafından hem ses kayıt cihazına kaydedilmiş hem de kısa notlar yoluyla denetlenmiştir. Böylece elde edilen verilerin anlamlı bir bütün oluşturulması 
Güzel P., Özbey S., Atalay Noordegraff M. (2012). Olimpik eğitimin yaygınlaștırılmasında üniversite oyunlarının etkileri. Uluslararası İnsan Bilimleri Dergisi [Bağlantıda]. 9:1. Erişim: http://www.insanbilimleri.com doi: 10.14687/ijhs.v9i1.2099

sağlanmıştır. Yapılan tüm bu çalışmalar araştırmanın iç ve dış geçerliliğini arttırıcı unsurlar olarak sağlanmıştır.

Araştırmada yapılan durum çalışmasında, bulunan sonuçlara nasıl varıldığının aşamalı, açık ortaya konması ve çıkarımlarla ilgili kanıtların diğer kişilerin ulaşılabileceği bir biçimde sunulması çalışmanın dış güvenirliğini arttırmıştır. Bu aşamalar; araştırma konusu ile ilgili kavramsal temelin oluşturulması, konu ile ilgili uzman kişiler ile birlikte görüşme sorularının hazırlanması, yapılan görüşmelerin betimsel ve içerik analizi tekniklerinden yararlanılarak kodlanması ve bunların sonucunda ana ve alt temaların oluşturulması şeklinde aşamalandırılmıştır. Ayrıca, Katılımcılarla yüz yüze görüşme süreci gerçekleştirilmiş, araştırmacı gerekli durumlarda -soruların farklı anlaşılması veya yorumlanmasıaçıklamalarda bulunularak ilgili konulara odaklanmalarını sağlamıştır. Araştırmanın iç güvenirliğinin sağlanması amacıyla ise elde edilen verilerden doğrudan alıntılar yapılarak betimleme ve kodlar oluşturma yolu uygulanmıştır. Betimsel analiz yöntemi ile ulaşılan sonuçlar, içerik analizi yöntemi ile de kodlanmış ve temalandırılmıştır. Verilerin kodlanmasında birden fazla araştırmacı kodlama yapmış ve bu kodlamalar karşılaştırılmıştır.

\section{Bulgular}

Dünyanın en büyük spor organizasyonlarından biri olan Üniversite Oyunları'nda Olimpizm anlayışının üstlendiği rol ile ilgili görüşlerinden elde edilen verilerin analizi sonucunda yapılan kodlamalarda üç ana tema ve alt temalar oluşmuştur.

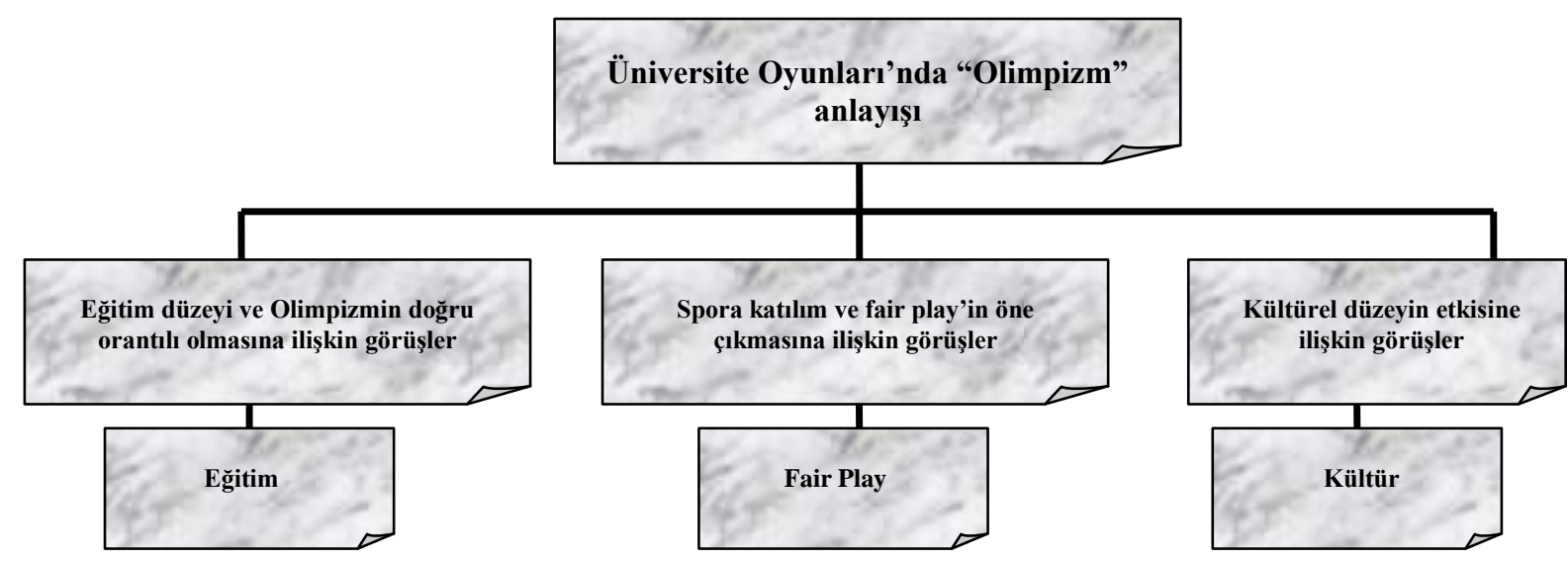

Şekil 2. 1. Genel Tema: Üniversite Oyunları ve Olimpizm Anlayışı 
Güzel P., Özbey S., Atalay Noordegraff M. (2012). Olimpik eğitimin yaygınlaştırılmasında üniversite oyunlarının etkileri. Uluslararası Insan Bilimleri Dergisi [Bağlantıda]. 9:1. Erişim: http://www.insanbilimleri.com doi: 10.14687/ijhs.v9i1.2099

1. Genel Tema ve alt boyutlarına ilişkin katılımcı görüşlerinden bazıları şunlardır:

"Sporcuların ĕgitim düzeyine bakıldı̆̆ında bu sayıda farklı branşın bir arada yapıldı̆̆ organizasyonlar içerisinde belki de en yüksek olan organizasyon Unıversıade' dir ve bu sporcular hem üniversite de okuyup hem de sportif alt yapıları kazanmış olmalarından dolayı spor kültürünü daha önce spor yapmış olmalarından ve eğitim düzeyinin bu denli yüksek olması ile ilişkisi olması gerektiğini düşünüyorum. Ayrıca bu organizasyonda çalışan yöneticiler, teknik ekip, personel ve gönüllülerin eğitim düzeyi ve yabancı dil özellikleri bakımından seçilerek alındığını biliyoruz” (A2).

“Olimpizm ideali gerçekleştirme anlamı taşır. Spor olgusunun spor olarak yaşanabilmesi, yarışmaların eşitlik ilkesi ile yapılması, estetik haz alınabilmesi önemlidir” (C4).

“Olimpizm anlayışı aynı zamanda kültür düzeyi ile paralel olduğu için olumlu yönde rolü vardır" (C5).

Katılımcıların, İzmir Üniversite Oyunları'nı “ticarileşme” faktörü açısından değerlendirmeleri ile ilgili elde edilen verilerin analizi sonucunda yapılan kodlamalarda bir ana tema ve bu ana temaya ilişkin alt temalar ortaya çıkmıştır.

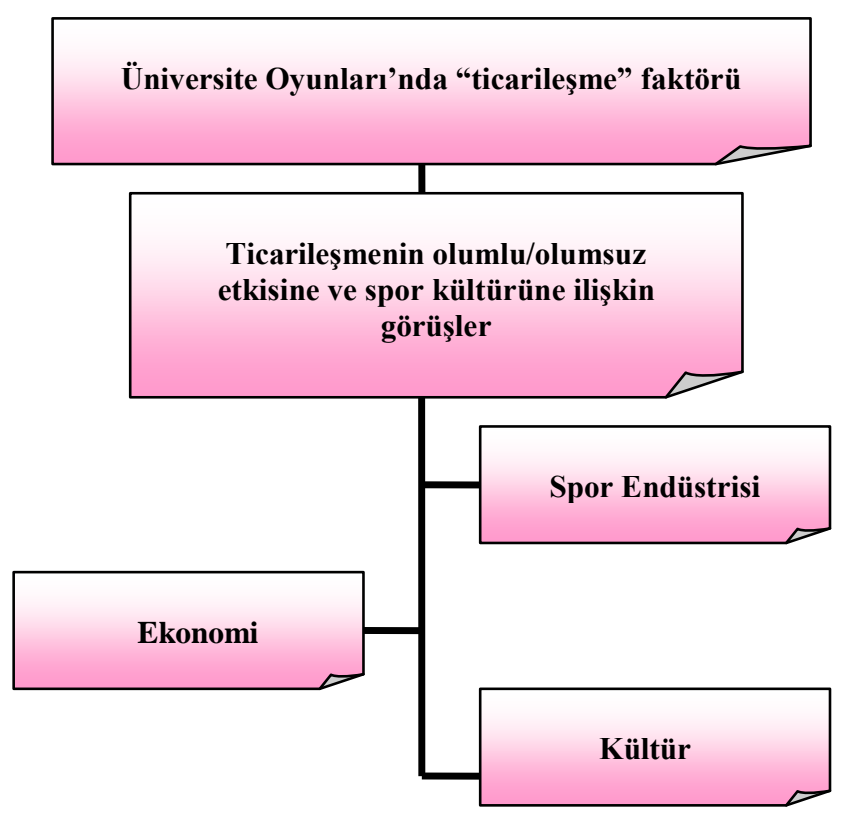

Şekil 3. 2. Genel Tema: Üniversite Oyunları ve Ticarileşme 
Güzel P., Özbey S., Atalay Noordegraff M. (2012). Olimpik eğitimin yaygınlaştırılmasında üniversite oyunlarının etkileri. Uluslararası Insan Bilimleri Dergisi [Bağlantıda]. 9:1. Erişim: http://www.insanbilimleri.com doi: 10.14687/ijhs.v9i1.2099

2. Genel Tema ve alt boyutlarına ilişkin katılımcı görüşlerinden bazıları şunlardır:

"Sporun bir endüstri olarak kabul edildiğinden yola çıkarak bu tür büyük bir organizasyon da bu spor endüstrisi içerisinde kendisine ciddi paylar almaktadır. Örneğin; seçilen tüm malzemeler uluslararası standartlarda ve önerilen markada olması gerekmektedir. Bu nedenle ciddi bir bütçe hazırlanarak ihtiyaç duyulan tesisler yapllmakta, malzemeler alınmakta ve gerekli personel yetiştirilerek karşıllı̆̆ da ödenmektedir. Aynı zamanda Universıade 2005'i sembolize eden hediyelik eşyalar, İzmir'in tanttımı, yiyecek-içecek, konaklama ve sağllk giderlerinin planlanması vb. işlemler de gerçekleştirilmektedir" (A2).

“Ticari ve sektörel açıdan izmir'e katkı sağlamış, birçok yan ticari faaliyetler ortaya sokmuştur" (C3).

“Bazı büyük kuruluşlar bu organizasyonda ciddi bir şekilde yer almıştır. Örneğin Coca Cola firması içecekleriyle (Powerade, vs.) organizasyonda ön planda göze batmıştır. Bu organizasyon sayesinde edinilen tesisler, malzemeler bize bir kazanç olarak kalmıştır. Ülkemizde bu organizasyonlardan sonra da spor kültürünün yaşaması için artılar olarak

Katılımcılara, Olimpiyatlara aday olan ülkemizde “eğitim” -özellikle BESYO’laraçısından Universiade 2005-İzmir'in katkı düzeyi ile ilgili elde edilen verilerin analizi sonucunda yapılan kodlamalarda "ana temalar" iki başlık altında toplanmıştır.

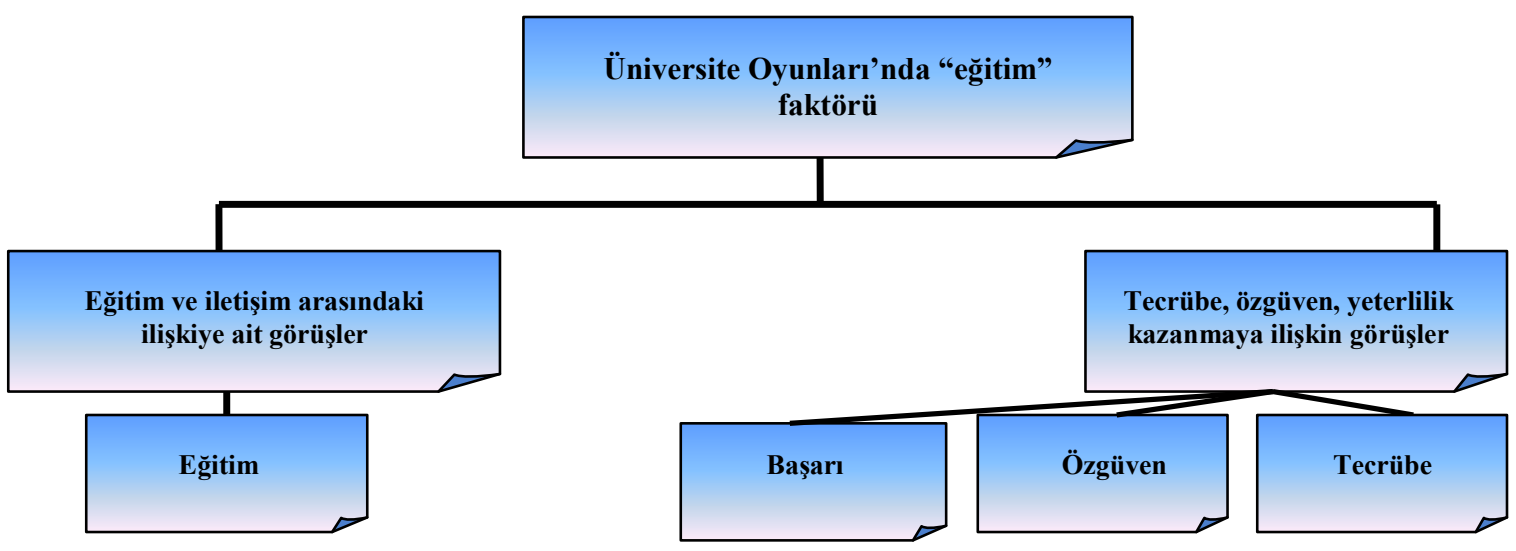

Şekil 4. 3. Genel Tema: Üniversite Oyunları ve Eğitim 
Güzel P., Özbey S., Atalay Noordegraff M. (2012). Olimpik eğitimin yaygınlaştırılmasında üniversite oyunlarının etkileri. Uluslararası Insan Bilimleri Dergisi [Bağlantıda]. 9:1. Erişim: http://www.insanbilimleri.com doi: 10.14687/ijhs.v9i1.2099

3. Genel Tema ve alt boyutlarına ilişkin katılımcı görüşlerinden bazıları şunlardır:

“Çok az katkı sağladı. Sadece İzmir'deki üniversitelerde çalışanlar bilgilendi. Dĭ̆er üniversiteler yeterli bilgilendirilmedi. Öncesi ve sonrası daha detaylı bilgilendirilebilirdi. Toplantılar yapılıp, tartışılabilirdi” (A1).

“BESYO ögrenci ve ögretim elemanlarının kendilerini test edebildiği ve neleri yapıp yapamayacă̆ı düşüncesinin olgunlaşması açısından önemlidir” (B1).

"3 aşamada bize katkı sağladığına inanıyorum. 1-) Uygulama alanında 2-) Teknik alanda 3-) Program geliştirmede. Uygulama alanında gerek ögrenciler gerekse ögretim elemanları uluslararası düzeyde ögrendiklerini uygulama düzeyleri hakkında deneyim sahibi olmuşlardır. Son olarak da teknik ve uygulama konusunda elde ettiğimiz deneyimlerle eksik olduğumuz konuları saptamak ve gerekli dersleri spor yöneticiliği programına ekleme

Katılımcıların "Profesyonellik” kavramının İzmir'deki Üniversite Oyunlarında yer alma durumu ile elde edilen verilerin analizi sonucunda yapılan kodlamalarda "ana tema" “amatörlük” başlığı altında toplanmıştır. Katılımcılar sporcuların ülkelerini temsil etmekten büyük bir hoşnutluk duyduklarını, yarışmacıların amaçlarının ne olursa olsun kazanmak değil katılım olduğunu ve Olimpizm olgusunun Oyunlar süresince sergilendiğini belirtmişlerdir.

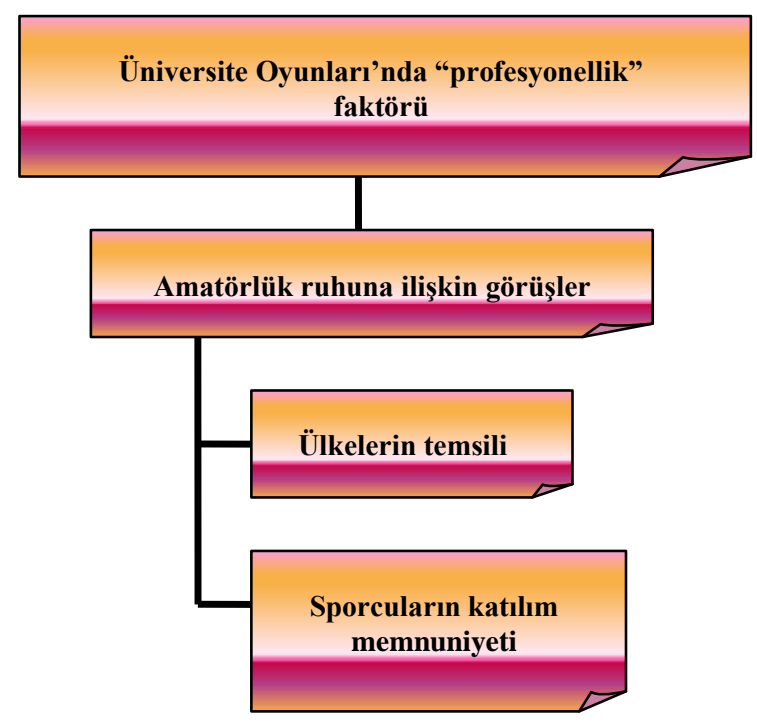

Şekil 5. 4. Genel Tema: Üniversite Oyunları ve Eğitim 
Güzel P., Özbey S., Atalay Noordegraff M. (2012). Olimpik eğitimin yaygınlaştırılmasında üniversite oyunlarının etkileri. Uluslararası Insan Bilimleri Dergisi [Bağlantıda]. 9:1. Erişim: http://www.insanbilimleri.com doi: 10.14687/ijhs.v9i1.2099

4. Genel Tema ve alt boyutlarına ilişkin katılımcı görüşü aşağıda yer almaktadır:

"Organizasyonda amatör sporcular çoğunlukla yarışmışlardır. Bazı sporcular ülkeyi temsil etmek, böyle bir yarışmada yer almaktan duyduğu mutlulukla yarlşılarken, bazıları da isim ve ödül için yarışmıştır. Ayrıca uluslararası ajanslardan gelen menajerler bu amatör sporcuları izleyerek aralarında sporcu seçimi yapmışlardır” (D1).

Katılımcıların Fair Play kavramının İzmir'deki Üniversite Oyunlarında ki durumu ile ilgili görüşlerinden elde edilen verilerin analizi sonucunda yapılan kodlamalarda; "Fair Play" ana teması altında iki alt tema ortaya çıkmıştır.

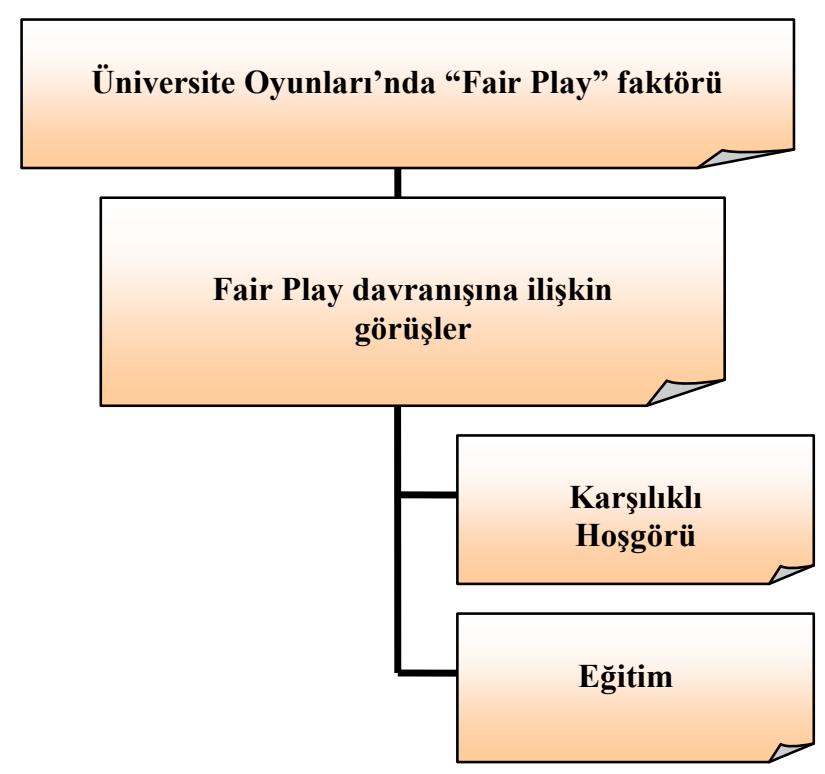

Şekil 6: 5. Genel Tema: Üniversite Oyunları ve Eğitim 
Güzel P., Özbey S., Atalay Noordegraff M. (2012). Olimpik eğitimin yaygınlaştırılmasında üniversite oyunlarının etkileri. Uluslararası İnsan Bilimleri Dergisi [Bağlantıda]. 9:1. Erişim: http://www.insanbilimleri.com doi: 10.14687/ijhs.v9i1.2099

5. Genel Temaya ilişkin tüm Katılımcılar, oyunlar boyunca Fair Play açısından olumsuz bir yaklaşımla karşılaşmadıklarını ve sporcuların sadece kazanmak arzusu ile yarışmadıklarını bunun da Fair Play’ in içinde yer aldığını belirtmişlerdir. Katılımcı görüşleri;

"Katılımcıların hepsi orada olmaktan dolayı mutluluk duymuşlardır. Madalyanın ötesinde yarışmak önem taşımıştır. Bu kavrama yakışmayacak herhangi bir durum söz konusu olmamıştır. Bu da bizim ülkemiz için bir başarı olmuştur” (D1).

“Benim bakış açımda spor ve centilmenlik birbiri ile yakından ilişkili kavramlardır. Özellikle de bu tür büyük spor organizasyonlarında ulaşılmak istenen hedef üniversite öğrencilerinin birbirlerini tanımaları ve anlamaları için yapılan sportif organizasyonlardır. Alınan altın madalyaların sayısından çok başarının farklı kriterlerinin de ön plana çıkarmak gerekmektedir. Bu da sporcu ögrencilerin birbirlerine, fiziksel performanslarına, yansıttıkları davranışlara ne kadar saygı gösterdikleri ve hoş görü ile yaklaştıkları ile çok yakından ilgilidir. Karşı takım ve ya sporcu bizim düşmanımız değil, orada oluş amacımızdır. Bu nedenle, özellikle spor kültürü ve eğitimi alan kişilerde fair play kavramının gelişmiş olması beklentisi içindeyim” (A2).

Katılımcıların "Evrensellik” kavramının İzmir'deki Üniversite Oyunlarında yer alma durumu ile ilgili ile elde edilen verilerin analizi sonucu yapılan kodlamalarda "evrensellik" ana temasının altında üç alt tema ortaya çıkmıştır.

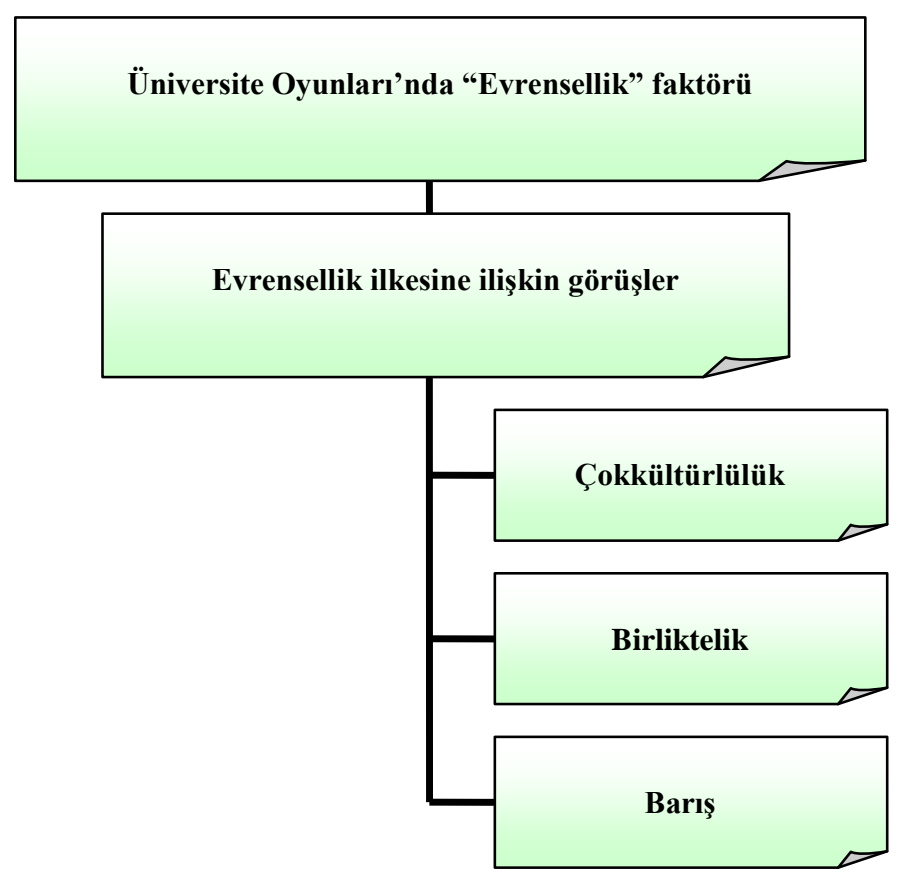

Şekil 7. 6. Genel Tema: Üniversite Oyunları ve Eğitim 
Güzel P., Özbey S., Atalay Noordegraff M. (2012). Olimpik eğitimin yaygınlaştırılmasında üniversite oyunlarının etkileri. Uluslararası Insan Bilimleri Dergisi [Bağlantıda]. 9:1. Erişim: http://www.insanbilimleri.com doi: 10.14687/ijhs.v9i1.2099

6. Genel Tema ve alt boyutlarına ilişkin katılımcı görüşü aşağıda yer almaktadır:

"Evrensellik benim için ahlaki ve etik değerlerdir. Spor da bu değerlerin kazanımında evrensel bir araçtır. Hatta daha da ileri giderek (bu tür “mega event” ler düşünüldüğ̈̈nde) spor olgusunun din, dil, ırk, etnik köken, fiziksel beceri düzeyi, v.b. gözetmeksizin her yaş ve cinsiyetteki insanlart etkileyen bir araya getiren, harekete geçiren, giyim ve yaşam tarzlarını dahi etkileyen evrensel bir olgu olduğuna inanıyorum. Ayrıca tıpkı yüzyıllardır dinlenilen bir klasik müzik parçası gibi spor da insanlığın var oluşundan bu yana etkinliliğini sürdürmüş ve ileride de sürdürecektir. Bu nedenle, Universiade-2005 organizasyonunda da bu evrenselliği yakından görmek ve anlama şansımız olmuştur. Çok çeşitli ülkelerden rekor sayıda sporcu ve katılımcı ile Universiade bize bu değerlerin varlığını hissettirmiş, hatta yaşatmıştır. Bu nedenle bu tür büyük katılımlı organizasyonların ülkemizde daha yaygın şekilde yapıllyor olması, bahsettiğimiz evrensel değerlerin verilmesi açısından oldukça önemlidir" (A2).

Spor Kültürü açısından İzmir'deki Üniversite Oyunlarını değerlendiren katılımcıların görüşleri ile ilgili elde edilen verilerin analizi sonucu yapılan kodlamalarda “spor kültürü” ile ilgili ana tema altında üç alt tema ortaya çıkmıştır.

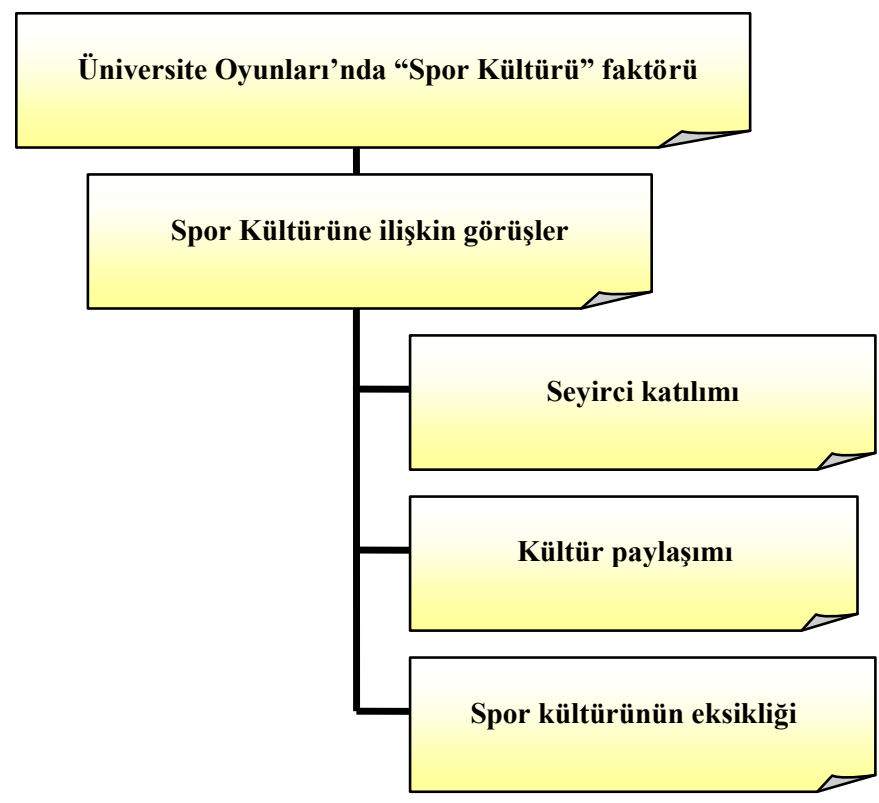

Şekil 8. 7. Genel Tema: Üniversite Oyunları ve Eğitim 
Güzel P., Özbey S., Atalay Noordegraff M. (2012). Olimpik eğitimin yaygınlaştırılmasında üniversite oyunlarının etkileri. Uluslararası Insan Bilimleri Dergisi [Bağlantıda]. 9:1. Erişim: http://www.insanbilimleri.com doi: 10.14687/ijhs.v9i1.2099

7. Genel Tema ve alt boyutlarına ilişkin katılımcı görüşü aşağıda yer almaktadır:

“Ülkemizde yok denecek kadar az olan Spor Kültürü, kendisini İzmir’de göstermiştir. Bazı branşları sporcuların dışında bir tek seyirci dahi izlememiştir. Büyük organizasyonlara hazır bir toplum olduğumuzu düşünmüyorum (C5)"

Katılımcılardan, Olimpik Eğitim Programı çalışmalarına dair önerileri ile ilgili katkılar istenmiştir. Katılımcılar Olimpik Eğitim çalışmalarının eğitim sistemi içerisinde yer alması gerektiğini belirtmiş ve çeşitli proje ve kurumsal çalışmalarla Olimpik Eğitimin tüm ülkede ve her kesimde yaygınlaştırılması gerektiğini bildirmişlerdir. Görüşmeler sonucunda ortaya çıkarılan temalar Tablo 3' de sunulmuştur:

Tablo 3. Katılımcıların Olimpik Eğitim Programına İlişkin Düşünceleri

\begin{tabular}{ll}
\hline \multicolumn{1}{c}{ Temalar } & \multicolumn{1}{c}{ Katılımcılar } \\
\hline Eğitim kurumlarının her basamağında işlenmesi & A1, A2, B2, C2, C4, D1 \\
Eğitim projeleri, Seminerleri ve yayınları ile duyurulması & A1, B2, C2, C3, C5 \\
Medya ve internette yer almasının sağlanması & A1, D1 \\
İlgili kurumların ortaklaşa çalışmaları & A2, B1 \\
\hline
\end{tabular}

Katılımcıların OEP ile İlgili Türkiye'de yapılan çalışmaları takip edebilme durumu ile ilgili elde edilen verilerin analizi sonucunda; Olimpik eğitimin spor eğitimi içinde yer alması zorunluluğu; OEP'nın duyurulması ve kurumlar arası iletişim ve OEP'nın uygulama güçlükleri şeklinde görüşler belirtilmiştir. Katılımcıların bu görüşleri içerisinde; Üniversitelerin spor bölümleri ile olan iletişim eksikliği; Projelerin içerisinde aktif yer alma; OEP'nın spor eğitiminin içinde yer alması gerekliliği; OEP'na erişilebilirlik ve internet ortamında yer alması zorunluluğu; Olimpik çalışmaların uygulamalarındaki güçlükler; Devlet politikalarında yer alması gerekliliği ve Olimpik eğitimin spor kültürünün oluşmasına yardımcı olması gibi görüşler yer almıştır.

Katılımcıların, Dünyada OEP ile ilgili yapılan çalışmalar hakkında bilgi sahibi olma durumları ile ilgili elde edilen verilerin analizi sonucunda; Eğitimde planlama zorunluluğu; Ülkelerin gelişmişlik düzeyi ve Olimpik eğitim çalışmalarının yoğunluğu doğru orantılı olması ve İnternet ortamında bilgiye ulaşma şeklinde görüşler belirtilmiştir. 
Güzel P., Özbey S., Atalay Noordegraff M. (2012). Olimpik eğitimin yaygınlaştırılmasında üniversite oyunlarının etkileri. Uluslararası Insan Bilimleri Dergisi [Bağlantıda]. 9:1. Erişim: http://www.insanbilimleri.com doi: 10.14687/ijhs.v9i1.2099

Katılımcıların bu görüşleri içerisinde; Kongre ve sempozyumlar yoluyla bilgi edinme; İnternet yoluyla bilgi edinme; Olimpik eğitim ile ilgili çalışmalar ülkelerin gelişmişlik düzeyi ile bağlantılı olması; Eğitim ile ilgili planlama yapma zorunluluğu ve Bilgi aktarımında eksiklik gibi görüşler yer almıştır.

Katılımcıların Üniversite/Bölümlerin OEP çalışmaları ile ilgili elde edilen verilerinin analizinde, katılımcılar Üniversitelerinde veya Bölümlerinde OEP ile ilgili çalışmaların yer aldığını belirtmişlerdir. Bu programların BESYO'ların ders müfredatlarında ve çeşitli seminer/projeler ile işlendiği ifade edilmiştir (Tablo 4).

Tablo 4: BESYO’ larda Olimpik Eğitim Programlarının Yer Aldığı Programlar

\begin{tabular}{lll}
\hline \multirow{2}{*}{$\begin{array}{ll}\text { Olimpik Eğitim Programının } \\
\text { sunulduğu programlarş̧malar }\end{array}$} & Dersler & Katılımcı \\
\cline { 2 - 3 } & Seminer,kongre,proje,vb. & A2,B2,B3,C1,C2,C3,C4,C5 \\
& Bed. Eğt. Öğr. Bölümünde işlenmesi & A1,A2,A3,B1,B2,C2,C3 \\
& Spor Yöneticiliği Bölümünde işlenmesi & A1,D1 \\
\hline
\end{tabular}

Katılımcıların OEP hangi düzeyde verilmeye başlanması ile ilgili elde edilen verilerin analizinde (Tablo 5), katılımcıların ortak görüşü OEP'nın ilköğretim eğitimi ile birlikte başlaması gerektiği yönünde olmuştur.

Tablo 5: Olimpik Eğitim Programı Başlangıç Düzeyi

\begin{tabular}{lll}
\hline & Hedef Kitle & Katılımcılar \\
\cline { 2 - 3 } Olimpik Eğitim & Lise & A1,A2,Bretim \\
Programı & Üniversite & \\
Başlangıç Düzeyi & İleri Akademik Programlar & \\
& Eğitim Kurumları Dışında & B1,B2,B3 \\
& Okul Öncesi Çağ & A3,C5 \\
& Tüm Basamaklarda Koordinasyon & A2,A3,D1 \\
\hline
\end{tabular}

Katılımcılar OEP'nın tüm basamaklarda koordineli bir şekilde yürütülmesi gerektiğini belirtmişlerdir. Ayrıca, eğitim kurumları dışında da Olimpik Eğitime destek verilmesi ve aile, spor kulüpleri, spor organizasyonları ve medya gibi Kurum ve Kuruluşlarda da Olimpik Eğitimin kazandırılmaya başlanması gerektiğini belirtmişlerdir. 
Güzel P., Özbey S., Atalay Noordegraff M. (2012). Olimpik eğitimin yaygınlaștırılmasında üniversite oyunlarının etkileri. Uluslararası İnsan Bilimleri Dergisi [Bağlantıda]. 9:1. Erişim: http://www.insanbilimleri.com doi: 10.14687/ijhs.v9i1.2099

Katılımcıların OEP hangi Kurum/Kuruluşlarca desteklenmesi ile ilgili verilerin analizinde (Tablo 6); OEP'nın tüm kurum ve kuruluşlarca destek görmesi gerektiğini vurgulamışlardır.

Tablo 6: Olimpik Eğitim Programına Destek Kurum ve Kuruluşlar

\begin{tabular}{lll}
\hline \multirow{2}{*}{ Olimpik Eğitim } & \multicolumn{1}{c}{ Kurum/Kuruluşlar } & Katılımcılar \\
\cline { 2 - 3 } Programı'na & MEB & A1,A2,A3,C1,C3,C4,C5 \\
Destek Kurum & TMOK & A1,A2,C1,C2,C3,C4,D1 \\
ve Kuruluşlar & Üniversiteler (BESYO) & A1,B1,B2,C1,C2 \\
& Diğer (Aile, Toplum,vb) & $\mathrm{A} 1$ \\
& & $\mathrm{~A} 1, \mathrm{~B} 3$ \\
\hline
\end{tabular}

\section{Tartişma}

Katılımcıların, dünyanın büyük spor organizasyonlarından biri olan Üniversite Oyunları'nda Olimpizm anlayışının, eğitim düzeyinin yüksek olması ile doğru orantılı olarak gördüğü saptanmıştır. Sporcuların hem eğitim süreçlerine devam edip hem de sportif alt yapı kazanmış olmaları onların spor kültürünü edinmelerinde önemli bir etkendir. 46. Uluslararası Genç Katılımcılar Oturumu'nda belirtildiği üzere; Olimpizm spor yarışmalarından daha öte bir kavramdır. Değerler ve idealler bütünüdür (arkadaşlık, fair play, spor eğitimi, mükemmel kişiliğe ulaşma çabası, barış, dayanışma, eşitlik, karşılıklı hoşgörü, kurallara ve insanlara sayg1, dürüstlük). Bu değer ve idealler kolaylıkla eğitim sistemi içine entegre edilebilir. Olimpizm kültürleri; ideolojileri, dinleri ve politik inançları aşan; insanları tüm geçmişlerinden ayrı, spor ve yarışma ruhu ile birleştiren bir güçtür. Bir başka deyişle; ayrımcılık gözetmeden spor ve fiziksel aktiviteler yolu ile insani değerleri öğrenme yoludur (IOA, 2006). Eğitim ve Olimpizm anlayışı birbirine bağıntılı kavramlardır. Olimpizmin tüm bu değerleri eğitim yolu ile aşılanırken, Üniversite Oyunları ve benzeri uluslararası spor organizasyonları da verilen bu eğitimin uygulama alanları olarak kullanmak mümkündür. $\mathrm{Bu}$ bulgu araştırmanın sonuçlarını destekler niteliktedir.

Katılımcılar Üniversite Oyunlarında 1rk, din, dil ayrımı gözetmeksizin, spor olgusunun eşitlik ilkeleri çerçevesinde sadece spor olarak yaşandığını ifade etmişlerdir. Sithole (2006)'un da belirtmiş olduğu gibi; spor organizasyonunun desteklediği insani değerler -barış, sosyal adalet, yaşamda fair play, insan gelişimi ve herkes için daha iyi yaşam standartları, 
Güzel P., Özbey S., Atalay Noordegraff M. (2012). Olimpik eğitimin yaygınlaştırılmasında üniversite oyunlarının etkileri. Uluslararası İnsan Bilimleri Dergisi [Bağlantıda]. 9:1. Erişıim: http://www.insanbilimleri.com doi: 10.14687/ijhs.v9i1.2099

insan hakları, eğitim, ırk ve din konularında eşitlik ve tolerans, kadın haklarının gelişmesi, çocukları koruma- IOC'nin kuruluşundan beri ilgilendiği temel ilkelerdir. Uluslararası spor karşılaşmalarında Olimpizm ruhu egemen kılınarak; ulusların kardeşliğine ve din, dil, ırk, cinsiyet ayrımı gözetmeksizin her insanın eşitliğine, kişiliğine saygı duyulmasına vesile olmalıdir (Atalay, 2004).

Araştırmada ortaya çıkan ve bu çalışmaları destekleyen bir başka görüş ise, Universiade 2005 İzmir'de de amacının yalnızca kazanmak değil böyle büyük çapta bir organizasyonda yer almak, dünya barışına katkıda bulunmak ve adil bir sportif performans sergilemek olduğu görülmüştür. İzmir adına açtıkları pankartlar, Oyunların düzenlenmesi için çok büyük katkılar sağlayan İzmir'in Oyunlar'dan önce ölen eski Belediye Başkanı için gösterilen ilgi, Oyunlar'da doping sorunun yaşanmaması, Olimpizm değerlerinin Üniversite öğrencilerince benimsenmiş olduğunun göstergelerindendir.

Katılımcılar, Olimpizm anlayışının kültür düzeyi ile paralel olduğunu ve bu durumun Üniversite Oyunları'nda olumlu bir şekilde yansıdığının gözlendiğini belirtmişlerdir. Olimpizm sporu, kültür ve eğitimle harmanlayan bir yaşam anlayışıdır. Üniversite Oyunları gibi büyük spor organizasyonları da bu anlayışın yaşanmasına olanak tanımaktadır. Birçok ülkenin kültürlerini, gelenek ve göreneklerini, yaşam tarzlarını yaşayarak öğrenme imkanı sağlamaktadır. Oyunlar süresince sporcuların bir arada yaşadıkları Oyunlar Köyü'nde kültürleri paylaşma imkanı doğmaktadır.

Universiade-2005 İzmir Yaz Oyunları'nda ticarileşme faktörü olumlu ve olumsuz olarak iki ayrı boyutta ele alınmıştır. Araştırmada, bazı katılımcılar ticarileşmenin spor kültürünün artmasında farkındalık yarattığını belirtirken, bazı katılımcılar da ticarileşmenin uluslararası organizasyonlara olumsuz etki yaptığını ifade etmişlerdir. Merih'in (2006) yapmış olduğu çalışma sonucunda; 1990'larda sporun ticarileşmesi ile Dünyanın ekonomik olarak az gelişmiş kesimlerinde bile spor olayları ve bunlara bağlı tüketim mallarının ticareti giderek ekonomide önemli, bir sektör haline dönüşmüştür. Sporla ilişkili endüstriler (spor teçhizatı, spor giyimi, araçlar, ayakkabılar, gıdalar v.s.) giderek toplumların sıradan tüketim kalemleri haline gelmiştir. Atalay’ın (2004) çalışması sonucu da, sporun artık medyatikleşmiş, profesyonelleşmiş, uluslararasılaşmış ve hepsinden önemlisi ticarileşmiş olduğudur. Medyanın spora bu yöndeki etkisinin yanısıra özellikle gelişmiş toplumlarda yaşanan sosyal ve ekonomik dönüşümler de sporun çehresini değiştirmiştir. İletişim teknolojisinin gelişmesiyle medyatikleşme ve buna bağlı olarak reklam ve sponsorluğun öne 
Güzel P., Özbey S., Atalay Noordegraff M. (2012). Olimpik eğitimin yaygınlaştırılmasında üniversite oyunlarının etkileri. Uluslararası İnsan Bilimleri Dergisi [Bağlantıda]. 9:1. Eriş̧im: http://www.insanbilimleri.com doi: 10.14687/ijhs.v9i1.2099

çıktığı ticarileşme Olimpik düşüncenin yara almasına sebep olmuştur. Katılımcılarda Oyunlar'ın İzmir'e ekonomik hareketlilik yaşattı̆̆ını ve bazı büyük kuruluşların (Adidas, Tansaş, vb.) bu organizasyonda sponsor veya destek olarak yer aldığını ifade etmişlerdir. Katılımcılar, organizasyonunun yapılmasına karar verenlerin olimpizm anlayışında olmalarına karşın saha ve tesislerin yapımında tamamen kar amacı güdüldüğünü, bazı kuruluşların ticari olarak zenginleştiği ile ilgili düşüncelerini ortaya koymuşlardır.

Katılımcılar özellikle BESYO'lar açısından Üniversite Oyunlarının eğitime çok büyük katkı sağladığını belirtmişlerdir. Özellikle organizasyonda görev alan Yöneticilerin ve öğrencilerin başarı, özgüven, yeterlilik duygusu kazandıklarını ifade etmişlerdir. Ayrıca, Üniversite Oyunlarının eğitim-öğretim programlarında tecrübe aktarımı konusunda kendilerine önemli katkılar yaptığı doğrultusunda görüş bildirmişlerdir. Bunların yanında bazı katılımcılar organizasyonda yaşanan iletişim eksikliği nedeniyle katkı sağlamak adına yeterince kazanım elde edemediklerini belirtmişlerdir. Singapur Olimpik Akademi Komisyonu'nun yayınlamış olduğu bildiride ortaya konan bir durum; Olimpizmin temel amaçlarından biri olan uluslararası anlayışın; insanların din, ırk ve siyasi inançlarındaki farklılıklarla baş edebilmeleri konusunda neyin farklı olduğunu ve birbirlerinin yaşamlarında neyin ilgi çekici olduğunu görebilmeleri konusunda cesaretlendirme hedefi güttüğü doğrultusundadır (Singapure Olympic Academy, 2006). Üniversite Oyunları gibi büyük uluslararası organizasyonların içerisinde yer almak ve başarılı bir tutum sergilemek kişiye katılımcılarında belirttiği gibi başarı, özgüven ve yeterlilik duygusu kazandırmaktadır.

Üniversite Oyunları'nda profesyonellikten çok amatörlük kavramının ön planda olduğu ifade edilmiştir. Ayrıca, üniversite öğrencilerinin maddi bir kazançtan çok, Oyunlarda ülkeyi temsil etmek, organizasyonun bir parçası olmaktan dolayı duyduğu haz gibi önceliklerinin olduğunu gözlemlediklerini belirtmişlerdir. Günümüzde sporda amatörlüğün ve profesyonelliğin çizgisini ayırmak oldukça güçleşmiştir. Amatörlük bir şeyleri severek yapmakla veya maddi kazanç olmadan ya da yaptığın işi profesyonel olarak yapmamakla yakından ilgilidir (Allison, 2001). Antik Olimpiyatlarda amatör sporcular eğlence ve yaptıkları aktiviteden zevk almak için spor yapmışlar ve kazanç sağlamamışlardır. Şu anda ise, sporcular için kazanmak her şeyden önemlidir. Ne kadar daha başarılı olurlarsa, o kadar daha çok para kazanılır düşüncesindedirler. Günümüzde oyunlar amatör ruhtan tamamen uzaklaşmıştır. Ödemeler ve ödüller kontrol edilemez hale gelmiştir (Tadesse, 1998). Buna rağmen, Üniversite Oyunlarında dünyanın dört bir yanından gelen belirli bir eğitim birikimine 
Güzel P., Özbey S., Atalay Noordegraff M. (2012). Olimpik eğitimin yaygınlaştırılmasında üniversite oyunlarının etkileri. Uluslararası İnsan Bilimleri Dergisi [Bağlantıda]. 9:1. Erişim: http://www.insanbilimleri.com doi: 10.14687/ijhs.v9i1.2099

sahip öğrenci sporcular günümüzde değerini oldukça yitirmiş olduğumuz amatörlük ruhunu tekrar yaşatmayı başarmışlar ve giderek önemli bir tehlike olarak karşımıza çıkan profesyonellik adına yapılan olumsuzlukları sergilemeyen bir tutum içinde Oyunlarda yer almışlardır.

Oyunlar boyunca Fair Play açısından olumsuz bir yaklaşımla karşılaşılmadığı ve sporcuların sadece kazanmak arzusu ile yarışmadıkları bunun da adil oyunun içinde yer aldığını belirtilmiştir. Fair Play kişisel çıkarları ve hırsları bastırarak yaşamda üstün insan ruhunu ortaya koymaktır. Sevgi, dostluk, kardeşlik anlayışı olan adil oyunun sınırı yoktur (Türkiye Fair Play Konseyi, 2009). Fair Play davranışına aykırı, yakışmayan hiç bir olay Oyunlar süresince sergilenmemiştir. Spor kültürü ve eğitimi alan kişilerde fair play kavramının gelişmiş olduğu beklenmiştir. Bu sevindirici durum da yapılan araştırmada ortaya konmak istenen ana temalardan birisi olmuştur.

Katılımcılar; Olimpizm kavramında yer alan evrensellik ve çok kültürlülüğün Oyunlar sırasında büyük ölçüde yaşandığını belirtmişler ve Oyunlar'da sporun kaynaştırıcı özelliğinin ortaya çıktığını gözlemlenmiştir. Evrensel felsefe, ulusu, ırkı, cinsiyeti, sosyal sınıfı, dini ne olursa olsun herkesi ilgilendiren bir kavramdır ve bu yüzden Olimpik Hareket, Olimpizm kavramı ile kendisinin tutarlı bir şekilde evrensel olarak temsili için çalışmıştır. Bunun sonucunda, Coubertin Olimpizm kavramının evrensel değerlerini fair play, eğitim ve çokkültürlülük olarak ifade etmiştir (Parry, 2000). Araştırma sonucunda da, dini, rrkı ve milliyeti olmayan spor olgusunun farklı kültürleri görme, tanıma, anlama ve kabul etme ortamının oluşturulması bakımından en önemli ve kapsamlı etkinliklerin başında yer aldığını belirtilmiştir. Türkiye'nin ve Ege Bölgesi'nin çok kültürlülüğü yaşayan bir coğrafya olduğu düşünüldügünnde Üniversite Oyunları'nda bu kavramın başarıyla gerçekleştirilmesinin beklenen bir durum olduğu söylenebilmektedir. Abreu'nun yapmış olduğu araştırmada da belirtildiği gibi; Olimpik çalışmalar, deneyimler ve bilimsel araştırmalarda Olimpizm değerleri beş kategori altında toplanmıştır. Bunlar: Fair Play; Herkes için Spor; Eğitimsel anlamda Spor; Spor aracılığı ile Kültürel Değişim ve Uluslararası Anlayış. Hem "Kültürel Değişim” hem de "Uluslararası Anlayış” yaklaşımları Olimpik Hareketin evrensel yönünü ortaya koyan değerlerdir. Çok kültürlülük ortamlarında her iki kategoride evrensel hakları somutlaştırmaktadırlar ve kültürler değişim düşüncesi üçüncü milenyuma girdiğimiz şu zamanlarda bir gereklilik halini almıştır (Abreu, 2001). 
Güzel P., Özbey S., Atalay Noordegraff M. (2012). Olimpik eğitimin yaygınlaştırılmasında üniversite oyunlarının etkileri. Uluslararası Insan Bilimleri Dergisi [Bağlantıda]. 9:1. Erişim: http://www.insanbilimleri.com doi: 10.14687/ijhs.v9i1.2099

Olimpizm ve Olimpik Eğitimin en önemli olgularından biri olan spor kültürü kavramı ile ilgili bulgularda katılımcıların çoğu seyirci ve sporcu arasındaki etkileşimin spor kültürüne katkısı olduğunu ve spor kültürünün uluslararası organizasyonlardaki farkındalığın artmasını sağladığını beyan etmişlerdir. Bazı katılımcılar ise, Türkiye'de spor kültürünün eksik olması nedeniyle, Oyunlara ilginin yeterli olmadığı görüşünü bildirmişlerdir. Türkiye'de spor kültürünün yeterince oluşmadığını belirten Ural'a gore; sporun bir kültür işidir ve davranışlarımızı belirleyen etken kültürdür. Çözüm olarak ise, üniversitelerde spor yapma olanaklarının yanı sıra spor kültürünün geliştirilmesi için özel olarak plan ve projelerin geliştirilmesi önerilmiştir (Ural, 2006). IOC Kültür Komisyonu Başkanı He'de 2001 yılında Roma'da düzenlenen Spor ve Kültür Forumu'nda, sporun kültür olmadıkça bir yere varamayacağı, etkinliklerde hiçbir kültürün dışlanmaması gerektiği, her kültürün kendisine has zenginliği olduğu, olimpik anlayışın temelinde ise bu kültür zenginliğinin yattığını belirtmiştir (Torakan, 2007).

Evrensel değerlere sahip spor organizasyonlarının barışa olumlu katkıları olduğunu ve Oyunlar sırasında aralarında problem yaşanan ülke sporcularının bile barış içerisinde yarıştıkları saptanmıştır. Katılımcılar üniversite gençliğinin evrensel değerler etrafında birleşmeyi amaç edinmesi ile dünya devletlerinin barışa olan bakış açılarını olumlu anlamda değiştirmeleri yönünden üniversite oyunlarının önemli bir spor organizasyonu olduğunu belirtmişlerdir. Coubertin "Ode to Sport” adlı yazmış olduğu şiirinde şöyle vurgulamıştır:

\footnotetext{
Ey spor! Sen barışsin...

Sen iyiyi, insanlara arkadaşlık ilişkilerini kabul ettirensin.

Sen antlaşmasin...

Insanları bir araya getiren, birleşmeyi arzu ettirensin.

Gençliğe farklı dilleri, saygı ve karllıkl güveni ögretensin.

Soyluluğun, barışçıl ve dostça yarışmanın kaynağısın.

Gençliği -geleceğimizi, umutlarımızı bayră̆ın altında toplayansın.

Ey spor! Sen barlşsın ... (Gerling, 2004).
}

Olimpik Eğitim çalışmalarının eğitim sistemi içerisinde yer alması ve her basamağında işlenmesi önemli bir bulgudur. $\mathrm{Bu}$ bulgu, diğer gelişmiş ülkelerin eğitim programlarına bakıldığında doğru bir tespit olarak karşımıza çıkmaktadır. Atina Olimpiyat Komitesi ve Yunanistan MEB yapılan çalışmalar sonucunda bu eğitim programını 1998-1999 
Güzel P., Özbey S., Atalay Noordegraff M. (2012). Olimpik eğitimin yaygınlaştırılmasında üniversite oyunlarının etkileri. Uluslararası İnsan Bilimleri Dergisi [Bağlantıda]. 9:1. Erişim: http://www.insanbilimleri.com doi: 10.14687/ijhs.v9i1.2099

eğitim-öğretim yılından itibaren uygulamaya geçirmiştir. Yunanistan gibi Almanya, Yugoslavya, Belçika, İspanya, Avustralya, Portekiz ve daha birçok ülkede bu çalışmalar çeşitli şekillerde eğitim sisteminin kademelerinde yer almaktadır.

OEP'nın sağlıklı bir şekilde uygulanabilmesi için ilgili tüm kurumların ortaklaşa çalışması ve koordinasyonun sağlanması gerektiğini belirtilmiştir. Bu kurumların başında MEB, GSGM, TMOK, Herkes için Spor Federasyonu ve Belediyeler gelmektedir.

Çalışmada “olimpik eğitim” tanımlaması yerine "spor eğitimi”, hareket eğitimi”" gibi sözcüklerin kullanılmasının daha etkin olacağını belirtilmiştir. "Olimpik eğitim” ilk olarak kullanan Pierre de Coubertin "hareket eğitimi”, "spor eğitimi” gibi kavramları da kullanmıştır. Burada "Olimpik eğitim” başlığı ile ortaya birbirinden tamamen bağımsız ya da karşıt kavramlar ortaya koymak gibi bir durum söz konusu olmamaktadır.

Oyunlar'ın Spor Yöneticilerine yeni bakış açıları kazandırdığını düşünenler (\%75) nedenlerini bazı etkenlere bağlamışladır. Bu etkenler; Olimpiyat Oyunları'ndan sonra en önemli spor organizasyonlarından biri sayılan Universiade sayesinde Uluslararas1 organizasyon deneyimi kazanılması, organizasyon esnasında ve sonrasında ne gibi eksikliklerin ortaya çıkabileceklerini görme ve bunlarla başa çıkabilme becerisi kazanılması, ülkemizde spor kültürünün eksikliğinin görülmesini sağladığg şeklindedir.

Katılımcılardan Oyunlar'ın Spor Yöneticilerine yeni bakış açıları kazandırmadığını düşünenler (\%25) ise; Oyunların organizasyonu sırasında "Spor Yöneticisi” tanımının net olmadığını gördüklerini, siyasetin spor organizasyonunun düzenlenmesinde fazlaca yer aldığını ve bunun da çeşitli olumsuzluklara (profesyonel anlamada orada olması gereken spor adamlarının politik nedenlerden dolayı etkinliğini yitirmesi, vb.) neden olduğunu, kurumlar arasında iletişim eksikliğinin sıkça yaşandığını dile getirerek soruya olumsuz olarak görüş bildirmişlerdir.

Katılımcılar, OEP ile ilgili çalışmaların ülkemizde yetersiz olduğunu belirtmişler ve bunu bazı sebeplere dayandırmışlardır. Bu sebepler; OEP'nın öncelikle bir devlet politikası olarak benimsenmesi gerektiği, spor eğitiminin içersinde yer alan, tüm kurumlarla özellikle de BESYO' larla işbirliği içerisinde çalışmalarını sürdürmelerinin gerekliliğidir. Türkiye'deki OEP'nı takip edemeyen katılımcılar (\%17), bu durumu çalışmaların yeterince koordineli sürdürülmediğini ve çalışmalara erişilebilirliğin güç olduğunu belirtmişlerdir.

Dünyada yapılan OEP ile ilgili çalışmaları takip eden (\%67) katılımcılar, Türkiye'nin aksine bu tür eğitim programlarına daha rahat ulaşabildiklerini belirtmişlerdir. Gerek internet 
Güzel P., Özbey S., Atalay Noordegraff M. (2012). Olimpik eğitimin yaygınlaştırılmasında üniversite oyunlarının etkileri. Uluslararası Insan Bilimleri Dergisi [Bağlantıda]. 9:1. Erişim: http://www.insanbilimleri.com doi: 10.14687/ijhs.v9i1.2099

teknolojisinden yararlanarak gerekse kongre, sempozyum ve seminerleri takip ederek bilgi edinebilmekte olduklarını ifade etmişlerdir. Bu durumun ülkelerin gelişmişlik düzeyleriyle yakından ilişkili olduğunu düşünen katılımcılar gelişmiş ülkelerde hem spor kültürünün kazanılmış olduğunu hem de kurum ve kuruluşlar arasındaki iletişimin üst seviyede olduğunu düşünmektedirler. Çalışmaları takip etmemiş olan \%33 oranındaki katılımcı grubu ise, ülkemizde bu konuda bilgi aktarımında eksiklik olduğunu ve bu yüzden çalışmaları takip etmede zorluk yaşadıklarını dile getirmişlerdir.

Katılımcıların \%75'inin üniversite ya da bölümünde OEP ile ilgili çalışmaların büyük bir çoğunluğu OEP'nın eğitim sistemimiz içerisinde henüz yeterince yer almadığı için daha çok eğitimcilerin kendi çabaları sonucunda derslerde işlendiği belirtilmiştir. \%25 oranındaki katılımcı grubu ise üniversite ya da bölümlerinin yeni yapılanma içerisinde olduğunu ya da kendi alanları olmadığı için programı takip etmediklerini ifade etmişlerdir.

Katılımcılar OEP’ nın önderliğini üstlenmesi gereken öncelikli üç kurum konusunda ortak bir düşünce ortaya koymuşlardır. MEB, GSGM ve TMOK'nin bu çalışmaların başında yer alması gerektiğini belirtmişlerdir. Atalay'ın (2004) yapmış olduğu çalışmada da, Hükümet ve Eğitim Bakanlığı'nın, Olimpiyat Komiteleri'nin bu programı desteklemesi tercih edilen kuruluşlar olarak ortaya çıkmıştır.

\section{Öneriler}

Araştırma konusu ile ilgili yapılacak çalışmaların sayısal olarak arttırılması ve uygulamalı çalışmalara da yer verilmesi önerilmektedir. Yöneticilere yöneltilen bu araştırma sonuçlarının OEP ile ilgili çalışmalar yapan öğrenciler tarafından da değerlendirilmesi ile programın etkinliğini arttırabileceği düşünülmektedir Olimpik eğitim ile ilgili araştırma yapan/yapacak kişilerin uluslararasında OEP'na katılıp, yayınları takip etmesi gerekmektedir. Araştırmacıların bu kazanımları ile ilgili kurum ve kuruluşlarla işbirliği içerisinde çalışması önerilmektedir. OEP'nın bilindiği fakat kavram olarak belirli bir noktada birleştirilerek adlandırılmadığı; Olimpik Eğitim kavramının Spor Yöneticileri tarafından hala bir felsefe olarak algılanmakta olduğu, eğitim sistemindeki olması gereken yerini henüz tam olarak alamadığı düşünülmektedir. Bu nedenle OEP ile TMOK'nde İlköğretim öğrencilerine spor kültürünü kazandırılması konusunda yapılan çalışmalar desteklenmelidir. Olimpik spor kültürünü geliştirme amacı ile, OEP çalışmalarının arttırılması ve ilgili kurum ve kuruluşların işbirliği içerisine girerek çeşitli projeler ortaya konulmasına ihtiyaç vardır. Yayınların ve 
Güzel P., Özbey S., Atalay Noordegraff M. (2012). Olimpik eğitimin yaygınlaştırılmasında üniversite oyunlarının etkileri. Uluslararası Insan Bilimleri Dergisi [Bağlantıda]. 9:1. Erişim: http://www.insanbilimleri.com doi: 10.14687/ijhs.v9i1.2099

çalışmaların izlenebilmesi için öncelikle üniversitelerin de programlarında gerekli düzenlemeler yapmaları önerilmektedir.

\section{Kaynaklar}

- Abreu N. (2001). “Olympism and Multicultural Education”, IOA, Report on the I.O.A.’s Special Sessions and Seminars, Ancient Olympia, Athens, p: 560-570

- Allison L. (2001), Amateurism in Sport, The Idea of Amateurism”, Routledge TaylorFrancis Group, p:3,5

- Altunışık R. ve Arkadaşları (2004), Sosyal Bilimlerde Araştırma Yöntemleri, Sakarya Kitabevi, s: 221

- Arnold P. (1996). “Olympism, Sport and Education”, QUEST, 48, p.93-101

- Atalay A. (2004). “Olimpiyatlar, Olimpik Ruh”, The 10th ICHPER-SD, European Congress and the TSSA 8th International Sports Science Congress, Antalya, November.

- Atalay M. (2004). “Uluslararası Olimpik Akademide Görev Alan Çeşitli Ülke Temsilcilerinin, Dünyada Olimpizm Düşüncesinin Yaygınlaştırllmasına Yönelik Görüşlerinin Analizi ve Türkiye Iç̧in Bir Değerlendirme”, Yayınlanmamış Doktora Tezi, Marmara Üniversitesi Sağlık Bilimleri Enstitüsü, İstanbul.

- Beijing Olympic Games, The Official Website, (2008). http://en.beijing2008.cn/education/heart2heart/index.shtml

- Binder D. (2004). "Teaching Olympism in Schools”, Olympic Education as a focus on values Education, Olympic Studies Centre CEO-UAB, http://olympicstudies.uab.es/eng/lec_2.asp?id_llico=14 Erişim: 20.02.2008.

- Garcia B. (2000). "Comparative Analysis of the Olympic Cultural Programs and Management of Barcelona 1992 and Sydney 2000”, http://www.la84foundation.org/SportsLibrary/ISOR/ISOR2000t.pdf_Erişim: 20.02.2008.

- Georgiadis K. (2001). IOA, “International Understanding Through Olympic Education”, ICHPER.SD, Vol:37, No:2, Special Olympic Issue, July.

- Gerling J. (2004). "The Idea of Peace in the Modern Olympic Movement: Origin, Development and Pedagogic Consequences", IOA, Report on the I.O.A.'s Special Sessions and Seminars, 2003, Ancient Olympia, Athens, p: 67-74 
Güzel P., Özbey S., Atalay Noordegraff M. (2012). Olimpik eğitimin yaygınlaștırılmasında üniversite oyunlarının etkileri. Uluslararası Insan Bilimleri Dergisi [Bağlantıda]. 9:1. Erişim: http://www.insanbilimleri.com doi: 10.14687/ijhs.v9i1.2099

- Gutenberg M.B. (1999). “Olympic Education in Germany”, 7th International Postgraduate Seminar on Olympic Studies, International Olympic Academy, Olympia.

- Güzel P. (2007). "Uluslararasl Spor Organizasyonlarının Olimpik Eğitimin Yaygınlaştırılması ile İlgili Etkileri: 23. Üniversite Yaz Oyunları”, Yayınlanmamış Yüksek Lisans Tezi, Celal Bayar Üniversitesi Sağlık Bilimleri Enstitüsü, Manisa,

- Güzel P. ve Özbey S. (2009). Olimpik Eğitim Programlarına Genel Bakış: "IOC 46. Uluslararası Genç Katılmcılar Oturumu, Olympia. Uluslararası İnsan Bilimleri Dergisi, Cilt:6, Say1:1.

- Hsu L. (2000). "OLYMPISM: A Dead Ideal and a Western Product”, Fifth International Symposium for Olympic Research pp. 249-256 http://www.la84foundation.org/SportsLibrary/ISOR/ISOR2000zf.pdf, Erişim: 20.02.2008.

- Hunterformer D. J. (2001). "Olympism for the Twenty First Century, New Life to a Timeless Philosophy”, The Sport Journal, Vol:4, No:1, p: 1-4

- International Olympic Academy (2006). 46th International Session For Young Participants, Consolidated Report (Workshop), Ancient Olympia- Greece.

- International Olympic Academy (IOA) Official Website, (2008). http://www.ioa.org.gr

- Loland S. (1995). "Coubertin's Ideology of Olympism from the perspective of the History of Ideas", OLYMPIKA: The International Journal of Olympic Studies, Volume IV, pp. 49-78

- Merih K. (2005). “Futbolun Küreselleşmesi”, Futbol Ekonomisi Stratejik Araştırma Merkezi.

- Muller N. (2004). “Olympic Education”, The Sport Journal, Published by the United States Sports Academy, Vol: 7, n: 1

- Naruka J.S. (2000). "Olympic Education in the Global Age: Perspectives and Advantages", IOA Report on the IOA's Special and Seminars, 1999, Ancient Olympia, Athens, p: 464-478

- Olympic Charter (2007). Published by IOC, Switzerland, http://multimedia.olympic.org/pdf/en_report_122.pdf Erişim: 12.04.2008

- Parry J. (2003). Globalization, Multiculturalism and Olympism, p: 86-97 
Güzel P., Özbey S., Atalay Noordegraff M. (2012). Olimpik eğitimin yaygınlaştırılmasında üniversite oyunlarının etkileri. Uluslararası Insan Bilimleri Dergisi [Bağlantıda]. 9:1. Erişim: http://www.insanbilimleri.com doi: 10.14687/ijhs.v9i1.2099

- Singapore Olympic Academy (2006). Olympic Education Kit, http://www.pess.nie.edu.sg/SOA/Intro.htm Erişim: 25. 04. 2008

- Sithole G. (2006). "The Endavors of the IOC for the Promotion of Olympic Education Programmes in Developing Countries", Presentation to the 8th Session of the International Olympic Academy, Olympia .

- Tadesse W. (1998) “Amateurs and Professionals at the Ancient Olympics: Problems and Prospects of Professionalism Today”, IOA, Report on the I.O.A.'s Special Sessions and Seminars, 1997, Ancient Olympia, Athens, p: 22,23

- Totrakan E. (2007). “Olimpik Anlayış ve Kültür”, http://www.ajansspor.com/ Erişim: 12. 06. 2008

- Türkiye Milli Olimpiyat Komitesi (TMOK) (2009). Türkiye Fair Play Konseyi Resmi Web Sitesi, http://www.fairplayturkiye.com/ Erişim: 15. 05. 2009

- Türkiye Milli Olimpiyat Komitesi (TMOK) (2010). Resmi Web Sitesi, http://www.olimpiyatkomitesi.org.tr Erişim: 20. 07. 2010.

- Türkiye'de İlköğretim Okulları 4. ve 5. Sınıflarda Spor Kültürü ve Olimpik Eğitim Kılavuz Kitabı (2004). TMOK Yayını, İstanbul, s:X

- Universiade (2005). İzmir, The Official Website, http://www.universiadeizmir.org.tr Erişim: 15.05.2007

- Ural Ş. (2006). “Spor bir Kültür İşidir”, İstanbul Üniversitesi Spor Dergisi, s: 3

- $23^{\text {rd }}$ Summer Universiade (2005). İzmir. Official Report. Vol. 1. Management. İzmir. 2006. Number Printed: 1350.

- Yıldırım A. ve Şimşek H. Sosyal Bilimlerde Araştırma Yöntemleri, (2005), Seçkin Yayınc1lı, Ankara, s: 35, 74, 107, 110, 259. 